\title{
An analytical study of iboga alkaloids contained in Tabernanthe iboga-derived products offered by ibogaine treatment providers
}

\author{
José Carlos Bouso ${ }^{1}$ \\ https://orcid.org/0000-0003-1115-9407 \\ IVAN ForNís 2 \\ https://orcid.org/0000-0001-8804-3256 \\ Mireia Ventura Vilamala ${ }^{2}$ \\ https:///rrid.org/0000-0003-1133-6872 \\ Benjamin De Loenen ${ }^{1}$ \\ https://orcid.org/0000-0002-7399-9076 \\ Alberto SaInZ-CorT ${ }^{1}$ \\ https://orcid.org/0000-0003-1168-464X \\ DANIEL F. JIMÉNEZ-GARRIDO ${ }^{1}$ \\ https://orcid.org/0000-0002-1775-754X \\ RAFAEL GUIMARÃES DOS SANTOS1,3,4 \\ https://orcid.org/0000-0003-2388-4745 \\ JAIME E. C. HaLlaK ${ }^{3,4}$ \\ https://orcid.org/0000-0002-8784-0189 \\ Miguel Ángel Alcázar-CóRcoles 5 \\ https://orcid.org/0000-0003-1650-2606 \\ Christopher W. JenKs 6 \\ https://orcid.org/0000-0002-7422-1637 \\ 1/CEERS Foundation (International Center for Ethnobotanical Education, Research \& Services), Barcelona, Spain \\ 2Energy Control, Asociación Bienestar y Desarrollo, Spain. \\ ${ }_{3}^{3}$ Department of Neurosciences and Behavior, Ribeirão Preto Medical School, University of São Paulo, Ribeirão Preto, SP, Brazıl. \\ ${ }^{4}$ National Institute of Science and Technology - Translational Medicine, Ribeirão Preto, SP, Brazil. \\ ${ }^{5}$ Departamento de Psicología Biológica y de la Salud, Facultad de Psicología, Universidad Autónoma de Madrid, Spain. \\ ${ }_{6}^{6}$ GITA (Global Ibogaine Therapy Alliance), Montreal, Canada.
}

Received: 05/14/2019 - Accepted: 06/03/2019

DOl: 10.1590/0101-60830000000231

\begin{abstract}
Background: Therapeutic properties of ibogaine in the treatment of addiction are attracting both clinicians and patients to its use. Since ibogaine is not an authorized medicine, the quality of these products is not always known, increasing the probability of adverse reactions. Objective: This study collects different types of iboga-derived samples from treatment providers, vendors and online buyers to analyse their content. Methods: Analysis of $i b o g a$ products $(\mathrm{n}=16)$ was performed using gas chromatography and mass spectrometry methods (GC/MS). Products included Iboga root bark, Total Alkaloids (TA), Purified Total Alkaloids (PTA HCl), ibogaine hydrochloride (ibogaine $\mathrm{HCl}$ ) and one Voacanga africana root bark. Results: The content of ibogaine was highly variable, ranging from $0.6 \%$ to $11.2 \%$ for products sold as iboga root bark, from $8.2 \%$ to $32.9 \%$ for products sold as TA, $73.7 \%$ for one sample sold as PTA and from $61.5 \%$ to $73.4 \%$ for products sold as ibogaine $\mathrm{HCl}$. One sample did not show any iboga alkaloids. Other alkaloids and unknown substances were found in almost all samples. Discussion: The purity of iboga products is highly variable. These results should be taken into consideration by suppliers and users, especially regarding correct dosing to avoid overdose, as well as potential interactions with other substances.
\end{abstract}

Bouso JC et al. / Arch Clin Psychiatry. 2020;46(2):51-4

Keywords: Tabernanthe iboga, ibogaine, sample analysis, addiction treatment, harm reduction.

\section{Introduction}

Ibogaine is a psychoactive alkaloid with hallucinogenic properties present in the root bark of Tabernanthe iboga, a tropical plant traditionally used in rites of passage and ethnomedicine in African countries such as Congo and Gabon ${ }^{1}$. Its anti-addictive properties were discovered serendipitously in the sixties by Howard Lotsof, who at that time was a heroin user and noticed that after using ibogaine his craving for heroin was significantly reduced. Since then, thousands of people have been treated with ibogaine to address drug dependence and/or for personal growth ${ }^{2}$.

Pre-clinical research has demonstrated the anti-addictive properties of ibogaine in different animal species with reductions in self-administered morphine, cocaine, (meth)-amphetamines, alcohol and nicotine ${ }^{3}$. Ibogaine was also found to reduce or eliminate drug craving and withdrawal in humans in several case series and in clinical settings, but randomized trials are lacking ${ }^{4-7}$.

Indeed, the number of ibogaine clinics and ibogaine treatment providers has been increasing during the last few years. In 2008 it was estimated that 3,414 people used ibogaine, approximately a fourfold increase relative to the estimation of 857 from five years before ${ }^{8}$. From those 3,414 subjects, $68 \%$ used ibogaine for the treatment of drug addiction. In New Zealand, Australia and South Africa, ibogaine can be prescribed for the treatment of drug addiction (the legal status of ibogaine around the world can be found at: https:// www.ibogainealliance.org/ibogaine/law/). Most of the iboga that is 
used in ibogaine clinics comes from Gabon, where unlicensed iboga exportation is forbidden. The lack of a regulated market results in a lack of quality control and patients may therefore be consuming ibogaine with unknown concentrations of active ingredients.

While ibogaine clinics are spreading around the world, accidents and fatalities have been increasing. By 201522 ibogaine-related deaths were reported 9,10 . Although ibogaine is considered a safe treatment when conducted under medical supervision ${ }^{11}$, many ibogaine providers offer ibogaine treatments outside of a medically controlled setting (for example, in hotel rooms). Furthermore, the purity of the ibogaine or iboga extracts used by treatment providers or self-administered by patients is frequently unknown, and. many clinics and private providers buy iboga/ibogaine from web-based suppliers without any quality control. This can increase the risks of adverse reactions and/or fatalities.

In one of the fatalities, the hypotensional substance reserpine ${ }^{12}$ was found in the blood of a man who died after ingesting ibogaine in Slovenia in $2011^{13}$. Reserpine might potentiate the hypotensional effects of ibogaine, increasing the risks of cardiovascular toxicity. Furthermore, both reserpine and ibogaine are metabolized by CYP-2D6 ${ }^{14}$ and this specific drug interaction could increase the blood levels of ibogaine, increasing the risk of overdose. This is especially relevant when most of the time the concentration of iboga alkaloids in ibogaine samples is unknown. Because the ibogaine sample involved in the fatality was not analysed, it is unknown if it contained reserpine or if the person used any other herbal or pharmaceutical product containing it. In the same year, reserpine was found in ibogaine samples analysed in Slovenia ${ }^{12}$. Forensic analyses after ibogaine fatalities regularly show the presence of other drugs in the body ${ }^{15}$.

Therefore, we performed this study to gain more insight into the purity and content of iboga samples available on the market, and to evaluate the claims made by the vendors about the characteristics of their products.

\section{Methods}

\section{Sample collection}

An advertisement was released through the website, newsletter and blog of the ICEERS Foundation (a non-profit organization that investigates the ethnobotany and therapeutic properties of iboga, ayahuasca, and cannabis) in July of 2013 (http://news.iceers. org/2013/07/scientific-study-analysis-of-iboga/) asking treatment providers, vendors and buyers to send samples for analysis. We requested information about (A) the type of material (root bark, iboga extract, ibogaine hydrochloride $(\mathrm{HCl})$, etc.); (B) the source (company, vendor, country, etc.); (C) date of purchase; (D) the expected percentage of ibogaine; $(\mathrm{E})$ any information about abnormal effects experienced, potency, etc.; and (F) any additional information considered relevant. Requested samples could include: (A) pulverized root bark; (B) total alkaloids (TA) (solid extracts containing the alkaloids present in the root bark); (C) purified total alkaloids (PTA) (solid extracts containing the semi-purified alkaloids in salt form); and (D) "pure" ibogaine $\mathrm{HCl}$.

\section{Samples preparation for GC/MS}

GC/MS qualitative and quantitative analysis was carried by Energy Control, a Spanish non-governmental organization with extensive experience in drug analysis. Their methodology for the GC/MS analysis has been previously reported ${ }^{16}$.

The samples were prepared by dissolving $5.0 \mathrm{mg}$ of each sample in $5.0 \mathrm{~mL}$ of methanol in glass vials. All vials were vortexed for 1 minute and then sonicated for 15 minutes.

The substances were determined with gas chromatography coupled with mass spectrometry (Agilent 7890B gas chromatograph coupled to a 5977A quadrupole mass spectrometer detector; (Agilent; Santa Clara, CA, USA) at the Municipal Institute for
Medical Research in Barcelona (IMIM - Hospital del Mar). The gas chromatograph was fitted with a G4513A auto-sampler injector. Samples were injected in split mode into a 30 meter, $0.25 \mathrm{~mm}$ i.d., $0.25 \mathrm{~mm}$ film thickness 5\% phenylmethylsilicone column (HP-5MS, Agilent Technologies). The oven temperature was initially maintained at $90^{\circ} \mathrm{C}$ for $2 \mathrm{~min}$ and programmed to reach $320^{\circ} \mathrm{C}$ at $20^{\circ} \mathrm{C}$ per min. It was finally maintained at $320^{\circ} \mathrm{C}$ for $9.5 \mathrm{~min}$. The total run time was $21.5 \mathrm{~min}$. Insert liners packed with silanized glass wool were used. The injector and the interface were operated at $280^{\circ} \mathrm{C}$. Helium was used as carrier gas at a flow rate of $1 \mathrm{~mL} / \mathrm{min}$. The mass spectrometer was operated in electron impact ionization mode at $70 \mathrm{eV}$. To confirm the mass spectra, two libraries were used: the Searchable Mass Spectral Library NIST/EPA/NIH Mass Spectral Library, Data Version: NIST 14 and the Searchable Mass Spectral Library Version 2.3 (http://www.swgdrug.org/ms.htm). A GC/MS comparison of the samples with the analytical standards of ibogaine, ibogamine, and voacangine was also performed. Ibogaine and voacangine were provided by Phytostan Inc., Montreal, Quebec. Analysis certificates of Phytostan Inc. alkaloids have been performed by the laboratory of Martin Kuehne, Department of Chemistru, University of Vermont, Burlington, Vermont, verifying the high purities of those alkaloids ${ }^{15}$. Ibogamine was provided by REFORM Italia srd.

\section{Data analysis}

The moles of ibogaine $\mathrm{HCl}$ in the Phytostan reference sample per unit of signal intensity for the ibogaine peak were calculated based on the injected mass. The moles of each detected component in a sample were then calculated based on its signal intensity relative to that of the Phytostan sample times the moles in the Phytostan sample. The mass of each component was calculated using its molecular weight, accounting for salt form. The mass percent of each component was then obtained by dividing the mass of each component by the mass injected for the sample.

\section{Results}

Table 1 shows all the information gathered from the received samples.

\section{Source}

We received 17 samples from five different known vendors during 2013. Samples were submitted from nine different countries with date purchases from 2006 to 2013. One of the 17 samples was excluded due to suspected contamination during handling.

\section{Samples}

The 16 remaining samples used were: iboga root bark $(n=6)$, iboga TA extract $(\mathrm{n}=5)$, iboga PTA $\mathrm{HCl}(\mathrm{n}=1)$, ibogaine $\mathrm{HCl}(\mathrm{n}=3)$, and Voacanga africana root bark $(\mathrm{n}=1)$. Of the six samples of iboga root bark, one was sold as coming from a supplier in Cameroon.

\section{Alkaloid content}

We were able to identify and quantify up to five different alkaloids from the samples (see Table 1).

Table 2 shows means and ranges of iboga alkaloids found in the analysed samples.

The alkaloid identification profile of the samples was similar for all products, except for one sample which did not contain any iboga alkaloid. The quantity of ibogaine was highly variable among the samples of each type of product and also among different types of products. High variability was especially worrying for the case of samples labelled as TA, which had the largest ibogaine variation. High variation in the content of ibogaine $\mathrm{HCl}$ samples was also found, possibly because some were actually PTA HCl based on all 
Table 1. Description of the samples

\begin{tabular}{|c|c|c|c|c|c|c|}
\hline Material & Date of Purchase & Country & Form & Color & $\begin{array}{l}\text { Expected ibogaine } \\
\text { concentration }\end{array}$ & $\begin{array}{l}\text { Quantitative analysis } \\
\text { (GC/MS) }\end{array}$ \\
\hline Iboga Root bark & Unknown & Australia & Powder & Light brown & -- & $A: 0,6 \%$ \\
\hline Iboga Root bark & 2006 & Netherlands & Fine chopped bark & Brown & -- & $\begin{array}{l}\text { All unknown } \\
\text { substances }\end{array}$ \\
\hline Iboga Root bark & $17 / 10 / 2012$ & New Zealand & Powder & Light brown & $2-4 \%$ & $\begin{array}{l}\text { A: } 11.2 \% \\
\text { C: } 0.7 \%\end{array}$ \\
\hline Iboga Root bark & $11 / 04 / 2012$ & Canada & Powder & Brown & -- & $\begin{array}{l}\text { A: } 2.1 \% \\
\text { C: } 0,3 \%\end{array}$ \\
\hline Iboga Root bark & $11 / 04 / 2012$ & Mexico & Powder & Light brown & -- & $\begin{array}{l}\text { A: } 9.9 \% \\
\text { B: } 0.1 \% \\
\text { C: } 0.6 \% \\
\end{array}$ \\
\hline Iboga Root bark & 03/04/2013 & Germany & Chopped bark & Brown & -- & $\begin{array}{l}\text { A: } 7.1 \% \\
\text { B: } 1.5 \% \\
\text { C: } 2.3 \% \\
\text { D: } 0.2 \%\end{array}$ \\
\hline Iboga extract-PTA & $11 / 04 / 2012$ & South Africa & Powder & Light brown & $80 \%$ & $\begin{array}{c}\text { A: } 73.7 \% \\
\text { B: } 4.7 \% \\
\text { C: } 6.1 \%\end{array}$ \\
\hline Iboga extract-TA & Unknown & Australia & Powder & Brown & -- & $\begin{array}{l}\text { A: } 9.1 \% \\
\text { B: } 2.3 \% \\
\text { C: } 0.6 \% \\
\text { D: } 0.2 \% \\
\text { E: } 0.1 \%\end{array}$ \\
\hline Iboga extract-TA & $07 / 04 / 2010$ & South Africa & Powder & Brown & $40 \%$ & $\begin{array}{c}\text { A: } 32.9 \% \\
\text { B: } 0.2 \% \\
\text { C: } 2.1 \% \\
\text { D: } 0.4 \% \\
\text { E: } 0.3 \%\end{array}$ \\
\hline Iboga extract-TA & $16 / 05 / 2012$ & New Zealand & Sticky raisin & Dark brown & $\begin{array}{c}35 \% \text { (sold as } 35 \% \text { of } \\
\text { ibogaine) }\end{array}$ & $\begin{array}{c}\text { A: } 25.4 \% \\
\text { B: } 0.5 \% \\
\text { C: } 16.4 \% \\
\text { D: } 0.6 \% \\
\text { E: } 0.6 \%\end{array}$ \\
\hline Iboga extract-TA & $16 / 08 / 2012$ & New Zealand & Pressed Powder & Dark brown & $\begin{array}{l}\text { Less than } 5 \% \text { (sold as } \\
35 \% \text { of ibogaine) }\end{array}$ & $\begin{array}{l}\text { A: } 13.3 \% \\
\text { B: } 0.2 \% \\
\text { C: } 1.6 \% \\
\text { D: } 0.1 \% \\
\text { E: } 0.1 \%\end{array}$ \\
\hline Iboga extract-TA & $11 / 10 / 2012$ & New Zealand & Powder & Dark brown & $\begin{array}{l}\text { Less than } 10 \% \text { (sold } \\
\text { as 35\% of ibogaine) }\end{array}$ & $\begin{array}{l}\text { A: } 8.2 \% \\
\text { B: } 0.2 \% \\
\text { C: } 0.8 \% \\
\text { D: } 0.1 \% \\
\text { E: } 0.1 \% \\
\end{array}$ \\
\hline Iboga extract-TA & $07 / 05 / 2013$ & Hawai USA & Powder & Light brown & -- & $\begin{array}{c}\text { A: } 61.6 \% \\
\text { B: } 7.2 \% \\
\text { C: } 7.1 \%\end{array}$ \\
\hline $\begin{array}{l}\text { Voacanga africana } \\
\text { Root bark }\end{array}$ & $03 / 04 / 2013$ & Spain & Pieces of bark & Brown & $\begin{array}{l}\text { 5-10\% carbometoxi- } \\
\text { ibogaina (voacangine) }\end{array}$ & $\begin{array}{l}\text { A: } 0.6 \% \\
\text { D: } 2.1 \%\end{array}$ \\
\hline Ibogaine HCL & Unknown & Australia & Powder & White & -- & $\begin{array}{l}\text { A: } 73.4 \% \\
\text { C: } 2.1 \%\end{array}$ \\
\hline Ibogaine $\mathrm{HCL}$ & $07 / 05 / 2013$ & Hawai USA & Powder & White & -- & $\begin{array}{l}\text { A: } 65.9 \% \\
\text { C: } 8.7 \%\end{array}$ \\
\hline
\end{tabular}

Note. A: ibogaine; B: ibogaline; C: ibogamine; D: iboleutine; E: voacangine.

Table 2. Alkaloid summary

\begin{tabular}{|c|c|c|c|c|c|c|c|c|c|c|c|c|c|c|c|}
\hline & \multicolumn{3}{|c|}{ Iboga Root Bark $(n=6)$} & \multicolumn{3}{|c|}{$\mathrm{TA}(\mathrm{n}=5)$} & \multicolumn{3}{|c|}{ Ibogaine $\mathrm{HCl}(n=3)$} & \multicolumn{3}{|c|}{ PTA HCI $(n=1)$} & \multicolumn{3}{|c|}{ V. africana $(n=1)$} \\
\hline & $\mathrm{N}$ & Ave. & Range & $\mathrm{N}$ & Ave. & Range & $\mathrm{N}$ & Ave. & Range & $\mathrm{N}$ & Ave. & Range & $\mathrm{N}$ & Ave. & Range \\
\hline Ibogaine & 5 & $6.2 \%$ & $0.6 \%-11.2 \%$ & 5 & $17.8 \%$ & $8.2 \%-32.9 \%$ & 3 & $67.0 \%$ & $61.6 \%-73.4 \%$ & 1 & $73.7 \%$ & -- & 1 & $0.6 \%$ & -- \\
\hline Ibogaline & 2 & $0.8 \%$ & $0.1 \%-1.5 \%$ & 5 & $0.69 \% \%$ & $0.2 \%-2.3 \%$ & 1 & $7.2 \%$ & -- & 1 & $4.7 \%$ & -- & 0 & -- & -- \\
\hline Ibogamine & 4 & $0.98 \%$ & $0.3 \%-2.3 \%$ & 5 & $4.3 \%$ & $0.6 \%-16.4 \%$ & 3 & $5.9 \%$ & $2.1 \%-8.7 \%$ & 1 & $6.1 \%$ & -- & 0 & -- & -- \\
\hline Voacangine & 1 & $0.2 \%$ & -- & 5 & $0.25 \%$ & $0.1 \%-0.6 \%$ & 0 & -- & -- & 0 & -- & -- & 1 & $2.1 \%$ & -- \\
\hline Iboleutine & 0 & -- & -- & 5 & $0.27 \%$ & $0.1 \%-0.6 \%$ & 0 & -- & -- & 0 & -- & -- & 0 & -- & -- \\
\hline
\end{tabular}


of them containing ibogamine and/or ibogaline in amounts similar to those for PTA HCl.

The expected concentrations of ibogaine in the samples (which were rated by the senders) were below our results in two cases, with a large difference in iboga root bark from Cameroon, which had almost three times more ibogaine than expected. The remaining samples rated by the senders were above our results, with the largest discrepancy observed in the V. africana sample, which was expected to have a concentration of $5 \%-10 \%$ of voacangine but showed less than $2.1 \%$

We also found unknown substances in several samples which we were unable to identify.

\section{Discussion and conclusions}

This is the first report analysing iboga products from on-line suppliers. Results show a large diversity of iboga alkaloid content in all the different products (iboga root bark, iboga extracts and ibogaine $\mathrm{HCl}$ ). This is especially meaningful for the ibogaine $\mathrm{HCl}$ samples, which are supposed to be purified. However, some ibogaine samples that have been used for scientific purposes in the past showed traces of ibogamine or ibogaline, even when the concentration of ibogaine was between $95 \%$ and $99.6 \%{ }^{17}$. Traces of ibogamine or ibogaline are to be expected in ibogaine isolated from the Tabernanthe iboga plant. During the analysis we also found substances other than iboga alkaloids in three of the samples, although we could not identify them. As noted above, we also found one sample that did not contain any iboga alkaloid. Also, two other samples contained less than $1 \%$ ibogaine. Low or zero concentrations of ibogaine should be of high concern. A recent report of a product sold as iboga bark was found to be Rauvolfia powder, which did not contain any iboga alkaloids and caused the death of the subject who used it thinking it was iboga root bark ${ }^{18}$.

The most relevant implication from these results is that ibogaine users are often not able to know the quality and purity of the purchased products when they come from on-line suppliers. Since many users and treatment providers obtain iboga/ibogaine for the treatment of addiction, they increase the potential risk of suffering side effects or adverse situations when they buy material of unknown quality from on-line suppliers. These adverse situations can include overdoses and fatalities ${ }^{15,19}$.

The contents of alkaloids in the iboga plant have a large variation and depend on many variables such as subspecies, growing environment, harvesting time, conservation of the samples, etc. Our results could be a reflection of the variability of alkaloid concentrations in iboga-derived products and its relationship with dosing difficulties. Important cardiovascular effects are observed at doses often used in drug-detoxification. Ibogaine needs to be provided in low doses to ensure safety ${ }^{20}$ and because the variability within iboga products can be a source of serious adverse reactions, this is an issue that should be taken into account by practitioners.

Given the high variability of ibogaine concentrations in ibogaderived products, both users and providers should be careful during dose calculations. At the same time, harm reduction programs should include qualitative and quantitative drug analysis to avoid overdosing and related fatalities. Since this 2013 analysis, the manufacture of high-purity ibogaine $\mathrm{HCl}$ from Voacanga africana bark has increased, offering treatment providers with a another way to avoid the quality issues inherent in using bark or crude alkaloids for treatment.

\section{Disclosures}

Role of Funding Source: This research did not receive any specific grant from funding agencies in the public, commercial, or not-forprofit sectors.

Contributors: JCB and BDL conceived of the study and collected the samples. JCB wrote the first draft of the manuscript. IF and MMV performed the analysis of the products. IF, MMV and CWJ interpreted the chemical analysis. BDL, ASC, DFG, RGD, JECH,
MAAC and CWJ contributed to data interpretation and literature review. All authors contributed to and have approved the final manuscript.

\section{Conflict of interest}

No conflict declared.

\section{Acknowledgements}

The authors would like to thank Ken Alper for critical reviewing of this manuscript. Also we want to thank Andrea Langlois for her help in editing the manuscript.

\section{References}

1. Fernandez JW. Bwiti: an ethnography of the religious imagination in Africa. Princeton: Princeton University Press; 1982.

2. Maciulaitis R, Kontrimaviciute V, Bressolle FMM, Briedis V. Ibogaine, an anti-addictive drug: pharmacology and time to go further in development. A narrative review. Hum Exp Toxicol. 2008;27(3):181-94.

3. Belgers M, Leenaars M, Homberg JR, Ritskes-Hoitinga M, Schellekens AFA, Hooijmans CR. Ibogaine and addiction in the animal model, a systematic review and meta-analysis. Transl Psychiatry. 2016;6(5):e826.

4. Cloutier-Gill L, Wood E, Millar T, Ferris C, Eugenia Socias M. Remission of Severe Opioid Use Disorder with Ibogaine: A Case Report. J Psychoactive Drugs. 2016;48(3):214-7.

5. dos Santos RG, Bouso JC, Hallak JEC. The antiaddictive effects of ibogaine: A systematic literature review of human studies. J Psychedelic Stud. 2016;1(1):20-8.

6. Schenberg EE, de Castro Comis MA, Alexandre JFM, Chaves BDR, Tófoli LF, da Silveira DX. Treating drug dependence with the aid of ibogaine: A qualitative study. J Psychedelic Stud. 2016;1(1):10-9.

7. Wilkins C, dos Santos RG, Solá J, Aixalá M, Cura P, Moreno E, et al. Detoxification from methadone using low, repeated, and increasing doses of ibogaine: A case report. J Psychedelic Stud. 2017;1(1):29-34.

8. Alper KR, Lotsof HS, Kaplan CD. The ibogaine medical subculture. J Ethnopharmacol. 2008;115(1):9-24.

9. Alper KR, Stajić M, Gill JR. Fatalities temporally associated with the ingestion of ibogaine. J Forensic Sci. 2012;57(2):398-412.

10. Koenig X, Hilber K. The anti-addiction drug ibogaine and the heart: a delicate relation. Mol Basel Switz. 2015;20(2):2208-28.

11. Kozelj G. Personal communication. January 19, 2016.

12. Mash DC, Kovera CA, Pablo J, Tyndale R, Ervin FR, Kamlet JD, et al. Ibogaine in the treatment of heroin withdrawal. Alkaloids Chem Biol. 2001;56:155-71.

13. Shamon SD, Perez MI. Blood pressure-lowering efficacy of reserpine for primary hypertension. Cochrane Database Syst Rev. 2016 21;12:CD007655.

14. Mash DC, Kovera CA, Pablo J, Tyndale RF, Ervin FD, Williams IC, et al. Ibogaine: complex pharmacokinetics, concerns for safety, and preliminary efficacy measures. Ann N Y Acad Sci. 2000;914:394-401.

15. Mazoyer C, Carlier J, Boucher A, Péoc'h M, Lemeur C, Gaillard Y. Fatal case of a 27-year-old male after taking iboga in withdrawal treatment: GC-MS/MS determination of ibogaine and ibogamine in iboga roots and postmortem biological material. J Forensic Sci. 2013;58(6):1666-72.

16. Giné CV, Vilamala MV, Espinosa IF, Lladanosa CG, Álvarez NC, Fruitós AF, et al. Crystals and tablets in the Spanish ecstasy market 2000-2014: Are they the same or different in terms of purity and adulteration? Forensic Sci Int. 2016;263:164-8.

17. Antonio T, Childers SR, Rothman RB, Dersch CM, King C, Kuehne M, et al. Effect of Iboga alkaloids on $\mu$-opioid receptor-coupled $\mathrm{G}$ protein activation. PloS One. 2013;8(10):e77262.

18. Gicquel T, Hugbart C, Le Devehat F, Lepage S, Baert A, Bouvet R, et al. Death related to consumption of Rauvolfia sp. powder mislabeled as Tabernanthe iboga. Forensic Sci Int. 2016;266:e38-42.

19. O'Connell CW, Gerona RR, Friesen MW, Ly BT. Internet-purchased ibogaine toxicity confirmed with serum, urine, and product content levels. Am J Emerg Med. 2015;33(7):985.e5-6.

20. Schep LJ, Slaughter RJ, Galea S, Newcombe D. Ibogaine for treating drug dependence. What is a safe dose? Drug Alcohol Depend. 2016;166:1-5. 